IZA DP No. 10345

Sexual Violence, Title IX and Women's

College Enrollment

Dave E. Marcotte

Jane E. Palmer

November 2016 


\title{
Sexual Violence, Title IX and Women's College Enrollment
}

\author{
Dave E. Marcotte \\ American University \\ and IZA \\ Jane E. Palmer \\ American University \\ Discussion Paper No. 10345 \\ November 2016 \\ IZA \\ P.O. Box 7240 \\ 53072 Bonn \\ Germany \\ Phone: +49-228-3894-0 \\ Fax: +49-228-3894-180 \\ E-mail: iza@iza.org
}

Any opinions expressed here are those of the author(s) and not those of IZA. Research published in this series may include views on policy, but the institute itself takes no institutional policy positions. The IZA research network is committed to the IZA Guiding Principles of Research Integrity.

The Institute for the Study of Labor (IZA) in Bonn is a local and virtual international research center and a place of communication between science, politics and business. IZA is an independent nonprofit organization supported by Deutsche Post Foundation. The center is associated with the University of Bonn and offers a stimulating research environment through its international network, workshops and conferences, data service, project support, research visits and doctoral program. IZA engages in (i) original and internationally competitive research in all fields of labor economics, (ii) development of policy concepts, and (iii) dissemination of research results and concepts to the interested public.

IZA Discussion Papers often represent preliminary work and are circulated to encourage discussion. Citation of such a paper should account for its provisional character. A revised version may be available directly from the author. 
IZA Discussion Paper No. 10345

November 2016

\section{ABSTRACT}

\section{Sexual Violence, Title IX and Women's College Enrollment}

Sexual violence has long been a problem on college campuses, yet federal policies to protect students have largely been ineffectual. Spurred by student grievances, the U.S. Department of Education's Office of Civil Rights recently began investigating how sexual assault cases were handled at a number of institutions under the Title IX provisions of the Education Amendments of 1972. These investigations focus attention on specific colleges' responses to cases of sexual violence and raise the specter that these institutions may fail to properly investigate allegations or punish perpetrators. In this paper, we examine the implications of these investigations on college enrollment, particularly for women. We combine institutionlevel panel data on enrollment by age and gender, with information on Title IX investigations to study changes in women's college enrollment. We estimate that enrollment of women at colleges under Title IX investigation declined by 16 to 22 percent. The declines are consistent with both declining matriculation and retention of female students.

JEL Classification: $\quad$ I24, J16

Keywords: college, educational attainment, sexual assault

Corresponding author:

Dave E. Marcotte

School of Public Affairs

American University

4400 Massachusetts Avenue NW

Washington, DC 20016-8070

USA

E-mail:marcotte@american.edu 
IZA Discussion Paper No. 10345

November 2016

\section{NON-TECHNICAL SUMMARY}

We assess the impact of high profile federal investigations of the handling of sexual assault claims at colleges and universities in the United States. Notably, we examine the impact of these investigations on student enrollment, rather than on outcomes one might expect would be most directly affected, such as rates of sexual assaults, supports for victims, and punishments for perpetrators. Sexual victimization and how a university handles those claims affect students beyond those directly involved. Our focus is broad because the climate and perceptions of a campus can affect the student body generally, and especially female students.

We find that enrollment of women of all ages drops following a Title IX investigation, with no similar changes for men. We estimate that the college enrollment decisions of more than 30,000 women changed as a result of a Title IX investigation, and more than two-thirds of this is due to declining retention at colleges under investigation.

Our paper illustrates that attention to the appearance of insufficient protections and processes at specific colleges had clear effects on the enrollment of women. That many women "voted with their feet" by leaving or avoiding institutions under investigation makes clear the stakes are high for colleges and universities. Since female students make up a sizeable majority of undergraduates, assuring that their safety and protection are paramount concerns will be essential for any college or university that hopes to thrive. 
College and university campuses have long been places where sexual violence against students is endemic. Though notoriously difficult to measure, ${ }^{1}$ studies consistently estimate that approximately 18 to 20 percent of undergraduate women are victims of sexual assault during college (National Institute of Justice, 2008). While high profile cases have recently focused attention on the issue,,$^{2}$ sexual violence on college campuses is not new. Indeed, the most important federal legislation aimed at protecting college students, the Clery Act, was passed more than 25 years ago. Unfortunately, there is little evidence that federal policies intended to reduce the incidence of sexual assault or protect victims have been effective.

The persistence of the problem along with perceptions of institutional failure led student activists in the 2000s to push the U.S. Department of Education to investigate claims that the failure to protect victims of sexual assault at some colleges resulted in unequal access to educational opportunity for women. The advent of this use of equal access requirements of federal law as a means to bring attention and remediation has resulted in a substantial shift in federal policy and public attention to the issue. In this paper we describe the growth in the use of investigations of individual colleges and universities by the U.S. Department of Education's Office of Civil Rights (OCR) in response to complaints filed under Title IX of the Education Amendments of 1972 -- established to prohibit discrimination on

\footnotetext{
${ }^{1}$ See Palmer and Perrotti (2016) and Fedina, Holmes \& Backes, 2016 for discussions of measurement issues.

2 Examples include a Columbia University student's years-long protest by carrying her mattress as a symbol of her victimization and the university's response (e.g. NY Times, Sept. 21, 2014) and the turmoil at the University of Virginia following a later-retracted article in Rolling Stone.
} 
the basis of sex in all activities at colleges and universities benefiting from federal funding. ${ }^{3}$

Because these investigations are based on complaints that institutions did not properly investigate or adjudicate instances of sexual violence, they may signal to current and prospective students that a college or university is not safe or does not take sexual assault seriously. In this paper, we assess this possibility by examining whether enrollment at colleges and universities is affected by the initiation of a Title IX investigation for failure to handle a credible allegation of sexual violence. Since women are overwhelmingly the victims of sexual violence, we examine whether enrollment of women decreases at an institution compared to men over the same period.

To do this, we compiled data on enrollment of full-time undergraduates by gender and age at all bachelor degree granting public and not-for-profit colleges and universities from 2005 through 2014. We merged data on where and when OCR opened Title IX investigations, obtained from the Chronicle of Higher Education's Title IX Tracker database. ${ }^{4}$ Using these combined data, we estimate event-study models of enrollment changes within a university by gender and age groups following the opening of an investigation. We find that enrollment of women of all ages drops following a Title IX investigation, with no similar changes for men. The enrollment declines for young (17 to 19 years old) undergraduate women may be

\footnotetext{
3 This effectively means all colleges and universities, because of the importance of federal student financial aid, including Pell Grants and subsidized loans.

${ }^{4} \mathrm{http}: / /$ projects.chronicle.com/titleix/
} 
due to declining application and matriculation rates. But the slightly higher declines among women in their early 20s is likely due to dropout and transfer.

We begin with an introduction to the issue, including describing the scope and dimensions of sexual violence on campus. We then briefly describe the institutional and judicial processes through which victims can seek redress, along with the development of Title IX investigations of student allegations of undue treatment.

\section{Background}

Campus sexual assault has long been the subject of study by researchers from the fields of criminology, psychology, social work and related fields. Estimates of sexual victimization can sometimes be difficult to compare, and can cause confusion among non-researchers. The difficulties arise because researchers use different reporting periods, have different rates of response in surveys (where subjects are asked necessarily sensitive and potentially traumatic questions), and researchers measure sexual victimization differently (Fedina, Holmes \& Backes, 2016; Palmer \& Perrotti, 2016).

For example, the first major study on sexual assault victimization among college women was Koss, Gidycz and Wisniewski (1987), in which the authors estimated that more than one in four college women had experienced attempted or completed rape. While Koss et al. (1987) measured victimization since the age of 14, not just since date of college matriculation, their estimates were quite similar to later estimates focusing only on victimization during college. For example, the 
National College Women Sexual Victimization study estimated that $20-25 \%$ of women would experience attempted or completed rape while attending college (Fisher, Cullen \& Turner, 2000). More recently, Krebs, et al. (2007) found that, within random samples at two large public universities, approximately 1 in 4 women experienced attempted or completed sexual assault using force or incapacitation since entering college. ${ }^{5}$ In the same year, Kilpatrick et al. (2007) reported that $5.2 \%$ of a national sample of 2,000 college women experienced completed rape using force or incapacitation in the past academic year, which over four years would be comparable to earlier estimates.

Note that the reference period (since 14, since entering college, past academic year) and how victimization was measured (sexual assault, attempted rape, completed rape) varies for each study. In addition, underreporting may be a larger issue for surveys that ask about rape, rather than a broader measure like unwanted sexual activity or sexual assault. Still, no matter the measure, the estimates are disturbingly high.

Although important issues in consistently measuring sexual violence across studies remain (Fedina, et al., 2016; Kruttschnitt, Kalsbeek \& House, 2014; Palmer \& Perrotti, 2016), there is solid evidence on the effects of sexual violence on victims. Trauma associated with experiencing sexual assault can result in depression, anxiety, post-traumatic stress disorder and a range of physical health issues that

\footnotetext{
5 The Koss et al. and Fisher et al. studies focused on measuring incidents that would legally be defined as rape. The Krebs et al. study measured incidences of "sexual assault", which is broader than "rape," but still includes illegal behaviors related to unwanted sexual activity (including rape and attempted rape) without consent.
} 
may impact a student's ability to complete a degree (Campbell, Dworkin, \& Cabral, 2009; Kilpatrick, et al., 2007).

\section{Policy Context}

The history of federal legislation to protect college students from criminal victimization begins with the Clery Act of 1990 . The main provision of Clery requires colleges and universities to make crime statistics publicly available and issue timely warnings of any ongoing threats to the campus population. Institutions are also required to provide victims with support in the aftermath of the crime and implement policies and procedures to ensure that victims are treated fairly during crime reporting and adjudication processes (US Department of Education, 2016).

Yet, institutions have a disincentive to encourage students to report, since crime statistics are publicly available and may affect public perceptions of the institution and future enrollment. For other reasons, too, critics have described the Clery Act as symbolic rather than substantial (Fisher, Hartman, Cullen \& Turner, 2002). The statistics that colleges and universities report are not inclusive of all crimes, because they are only required to report crimes that occurred on or near campus or campus property. In addition, the failure to distinguish between crimes in which students (or employees) are victims or perpetrators has meant that reported data does not distinguish between dangerous campuses and dangerous cities in which colleges are situated. A further complication arises because of the general reluctance of students to report sexual assault to authorities (Fisher et al., 2000). As a result, higher sexual assault statistics may be indicators of a campus 
climate conducive to increasing student willingness to report assaults, rather than underlying victimization rates (Cantalupo, 2011; Palmer \& Alda, 2016).

The Violence Against Women Act (VAWA), first authorized in 1994 as part of the Violent Crime Control and Law Enforcement Act (H.R. 3355), supplemented federal law to protect students (and others) on college and university campuses (Dunn, 2013; Schroeder, 2013). In 1999, the first Campus Grants, using VAWA funds, were awarded to support initiatives to prevent and respond to violent crimes against women on college campuses. In addition to granting funds such programs, the law also requires colleges and universities to offer sexual assault prevention programs for all incoming students and new employees. In addition, VAWA outlines several procedural requirements related to adjudication process in cases of sexual violence to assure transparency, and also confidentiality for the victim.

\section{The Use of Title IX to Combat Sexual Violence}

In 2011, the U.S. Department of Education's Office of Civil Rights released a "Dear Colleague Letter" (DCL) ${ }^{6}$ that clarified the requirements of Title IX in the context of sexual violence at all public and private schools, colleges and universities that receive federal financial assistance. Title IX is a civil rights law passed as part of the Higher Education Amendments of 1972 to assure equal access to education. The initial implementation of this law focused on female students' access to sports and equitable athletic facilities. Over time, the law was interpreted to include other forms of sex-specific discrimination that affect female students' equal access to

\footnotetext{
${ }^{6}$ See http://www2.ed.gov/about/offices/list/ocr/letters/colleague-201104.html
} 
education. The OCR is responsible for investigating any complaint that an educational institution violated Title IX.

The DCL clarified that Title IX requires a prompt and equitable investigation if the school is aware of an allegation of sexual harassment or sexual violence. If a school "knows or reasonably should know" of an instance of sexual harassment or sexual violence, it is required to immediately complete a "prompt, thorough and impartial" investigation. Any adjudication process must use a preponderance of evidence standard, which is a lower burden of proof than the beyond a reasonable doubt standard used for sexual assault cases in the criminal justice system. If the adjudication process results in a finding that sexual violence occurred, the institution must "take immediate action to eliminate the hostile environment, prevent its reoccurrence, and address its effects" (DCL, 2011, p.15). If a victim believes any of these steps were not followed adequately, she or he can elect to file a complaint with OCR within 180 days. If OCR determines the college or university does not respond in promptly and equitably, it may indicate the institution violated Title IX. Schools that are found to be non-compliant can face fines, lose federal funding and be required to take steps to remedy or correct their response to sexual violence.

\section{Title IX and Public Awareness}

The OCR's action was largely in response to growing public attention to the issue of campus sexual assault and how it was being handled. In 2010, National Public Radio and the Center for Public Integrity released a series on failure by colleges to protect women from campus rape. Their investigations found that 
colleges rarely expel sexual assault perpetrators and prevention programs put the responsibility on women to prevent rape. They presented their findings directly to the Assistant Secretary for OCR, who committed to more aggressively address sexual violence on college campuses (NPR, 2010). More recent examples of public attention include the 2015 documentary film The Hunting Ground, which offered several survivors' perspectives of how their universities did not properly respond to their allegations of sexual assault, and follows two activists who began to teach their peers how to file a complaint with the OCR. The same year a widely read book on the handling of sexual violence cases by the University of Montana and the local police helped to further raise the public's awareness of the institutional protectionism and inadequate response that many students face when they report sexual violence to university administrators (Krakauer, 2015).

For many, the realization that sexual violence was endemic on college campuses and that institutions were not properly responding to these crimes, was somewhat of a shock to the general sense of real advances for women in higher education. The share of women enrolling in and graduating from college has long been growing. Women's undergraduate enrollment surpassed men's enrollment in the late 1970 s and by 2009 , there were approximately 132 women enrolled in American colleges and universities for each 100 men (Aud et al. 2011). However, the campus setting is a unique place for both raising the risk of sexual assault and for clouding the process of protecting victims and punishing criminals.

The OCR's increase in Title IX investigations have focused substantial attention on issues of climate and safety for women. Each new investigation is 
widely covered in national news, and the Chronicle of Higher Education has devoted special attention to each case. ${ }^{7}$ In May of 2014, for the first time ever, OCR made public the list of 55 higher educational institutions with open Title IX investigations related to sexual violence. As of September 2016, there are 277 open sexual violence investigations at 214 colleges and universities.

Unlike Clery, which provides general information about crime statistics, Title IX investigations have focused attention on sexual assault at specific institutions, and how these schools handle victims' complaints, and how they treat offenders. Consequently, Title IX investigations may cause real concern among prospective and current students about school climate. These cases may be seen as warning signs about the extent of sexual victimization on a given campus and the degree to which students' complaints are taken seriously and judiciously processed. Below, we describe our methods for examining whether the opening of a Title IX investigation affects enrollment at a college or university.

\section{Data and Model:}

To study the impact of a Title IX investigation on student enrollment, we use data from the Integrated Postsecondary Education Data System (IPEDS) for academic years 2006-07 through 2013-14. We restrict our analyses to public and non-profit institutions that grant bachelor's degrees. Therefore, we omit all forprofit and two-year colleges. The IPEDS institutional data includes information on the cost of attendance in each year including tuition and fees and financial aid, along with other factors that would affect enrollment. These include selectivity as

\footnotetext{
${ }^{7}$ http://projects.chronicle.com/titleix/
} 
measured by admission rate and graduation rates, measured as the proportion of matriculating freshmen receiving a bachelor's degree within six years. We also include measures of university types: distinguishing between research-intensive (Ph.D. granting) universities, and those offering mainly master's degrees as their highest degrees, separate from traditional bachelor's granting liberal arts colleges. On all of these dimensions we distinguish between non-profit and public universities.

The IPEDS also provides detailed enrollment data by age, gender, and level of study (undergraduate vs. graduate) for each institution. This enrollment (headcount) data is recorded in the Fall of an academic year and is usually reported annually, however it is only mandatory biennially. So, for some smaller colleges we observe group-specific enrollment only every other year. ${ }^{8}$ We combine the institutional and enrollment data to construct a data set of year-specific enrollment in all public and non-profit colleges that grant bachelors degrees, by age and gender between 2006 and 2014 .

To this dataset, we add information on Title IX investigations from the Chronicle of Higher Education's Title IX Tracker database, which compiles information from Freedom of Information Act requests of the U.S. Department of Education..$^{9}$ The information on cases in the Title IX Tracker varies by institution. However, all case files include a date on which the OCR determined that a complaint had merit and opened an investigation into the handling of a complaint of sexual violence by an institution.

\footnotetext{
${ }^{8}$ We discuss the implications of this for our empirical models below.

${ }^{9} \mathrm{http}: / /$ projects.chronicle.com/titleix/
} 
To measure impacts of Title IX, we generate indicators of whether a college or university had an investigation open in an academic year. We assign an investigation to an academic year if OCR notified the institution by May of that year. So, we would classify a notice issued in June 2011 as occurring in the 2011-12 academic year. We recognize that an indicator variable of a case opened in an academic year is a crude measure of enrollment effects: It might take time for matriculating or prospective students to react or current students to transfer if a Title IX investigation was a source of concern. Or, it could be that cases of sexual violence that are brought to the U.S. Department of Education are sources of upset at a university before any Title IX investigation is launched. To measure these possibilities, we estimate models with both leading and lagging indicators of Title IX investigations.

We use these data to estimate the impact of Title IX investigations on enrollment using models of the following type:

$$
\text { lnEnroll }_{s g t}=\alpha+\beta_{1} X_{s t}+\sum_{g} \delta_{g} \text { TitleI }_{s t}+\theta_{g}+\tau_{t}+\gamma_{s}+\epsilon_{s g t}
$$

where the dependent variable is the log of enrollment of full-time students at school $\mathrm{s}$, in year $\mathrm{t}$ for each of four groups (g). The groups are 1) Women from 17-19 years old, 2) Men from 17-19 years old, 3) Women 20 to 24 years old, and 4) Men from 20 to 24 years old. Enrollment is logged because it is highly positively skewed. We include a series of control variables $\left(\mathrm{X}_{\mathrm{st}}\right)$ likely to affect enrollment, such as tuition and fees and the percent of students receiving aid; the admission and (6-year) graduation rates and the share of all students in undergraduate versus graduate 
programs. TitleI $X_{s t}$ is an indicator of whether institution $s$ was under investigation in academic year $t$. The coefficients of interest are the $\delta^{\prime} s$ which measure enrollment changes for each group coincident with a Title IX investigation. We control for both year and institution fixed effects, so the $\delta^{\prime} s$ measure changes in each group's enrollment within an institution at the outset of an investigation, net of year and group specific enrollment effects more generally. All standard errors are clustered at the college/university level, and we restrict our analyses to colleges with a total enrollment of more than 100 students.

Our models are similar to the standard difference-in-differences parameterization of a model wherein one compares groups affected/unaffected by an event/policy. Since women are overwhelmingly the victims of sexual violence, and the vast majority of Title IX investigations are in response to cases brought by women, one might expect different responses from female and male students. However, the enrollment of male students may also be affected by the negative attention brought on to a college by an investigation. So, we estimate enrollment responses for all groups, and test for between-group differences.

Two illustrative cases of how female and male students might respond to a Title IX investigation are Michigan State and the University of Montana. Figure 1 shows enrollment of young women and men at Michigan State. Before the OCR opened a Title IX investigation for Michigan State's handling of a sexual assault of a student (represented by the vertical line), the undergraduate student body was majority female. Leading up to the investigation, the number of female students fell (by about 800 , or 10 percent), while the number of male students grew. This is in 
contrast to patterns at the University of Montana (Figure 2), where enrollment fell for both men and women. Montana was the subject of intense media scrutiny following two accusations of rape against football players (see Krakauer, 2015).

Figures 1 and 2 illustrate another important issue. Because Title IX investigations are initiated after an unsatisfactory campus adjudication process, they lag assaults and the publicity and protests that can embroil a college in their wake and during the process. As a result, we also estimate models that include indicators for the years before a Title IX investigation. We also include an indicator of the year after, to assess whether enrollment effects are short-lived.

\section{Figure 1}

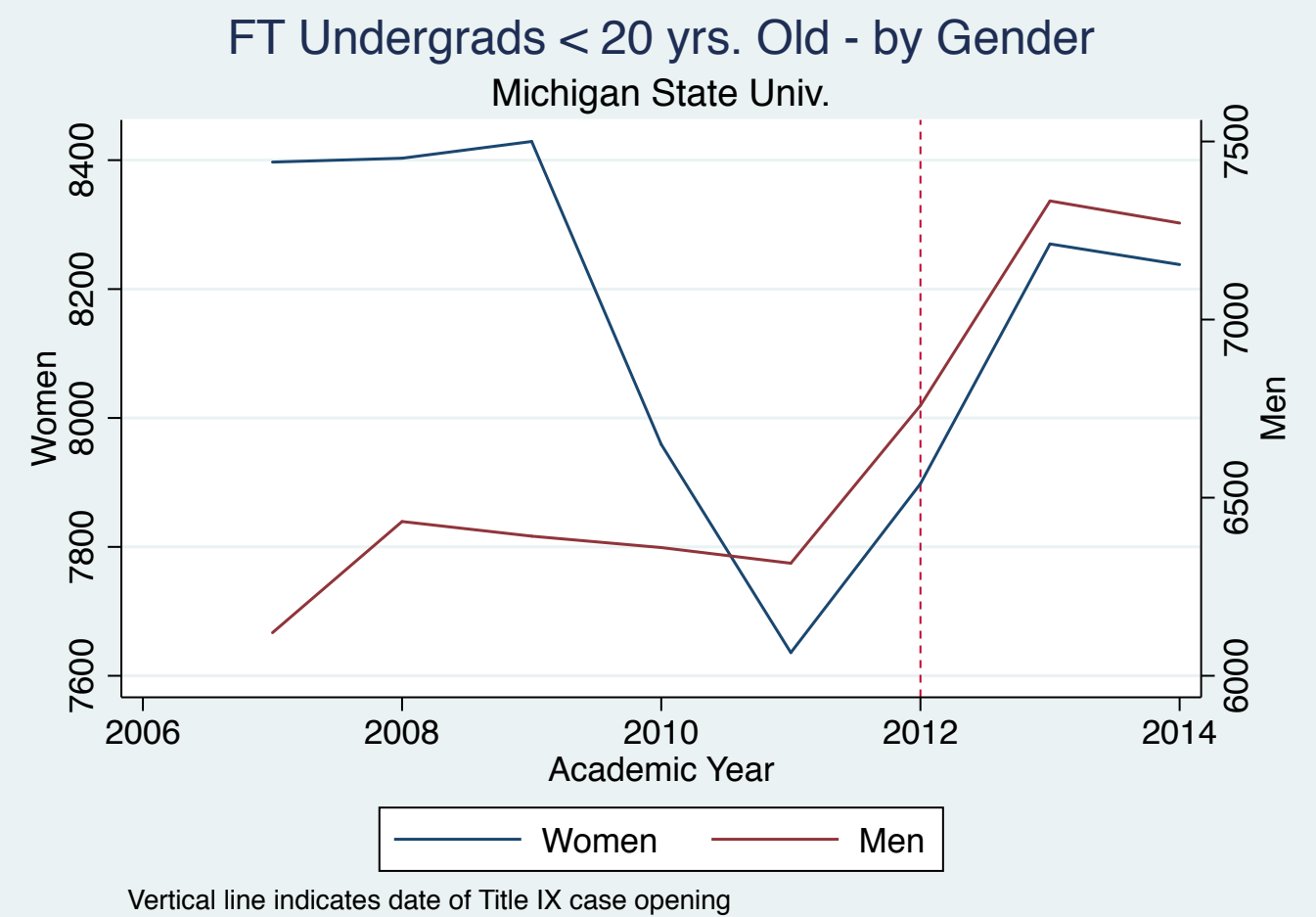


Figure 2

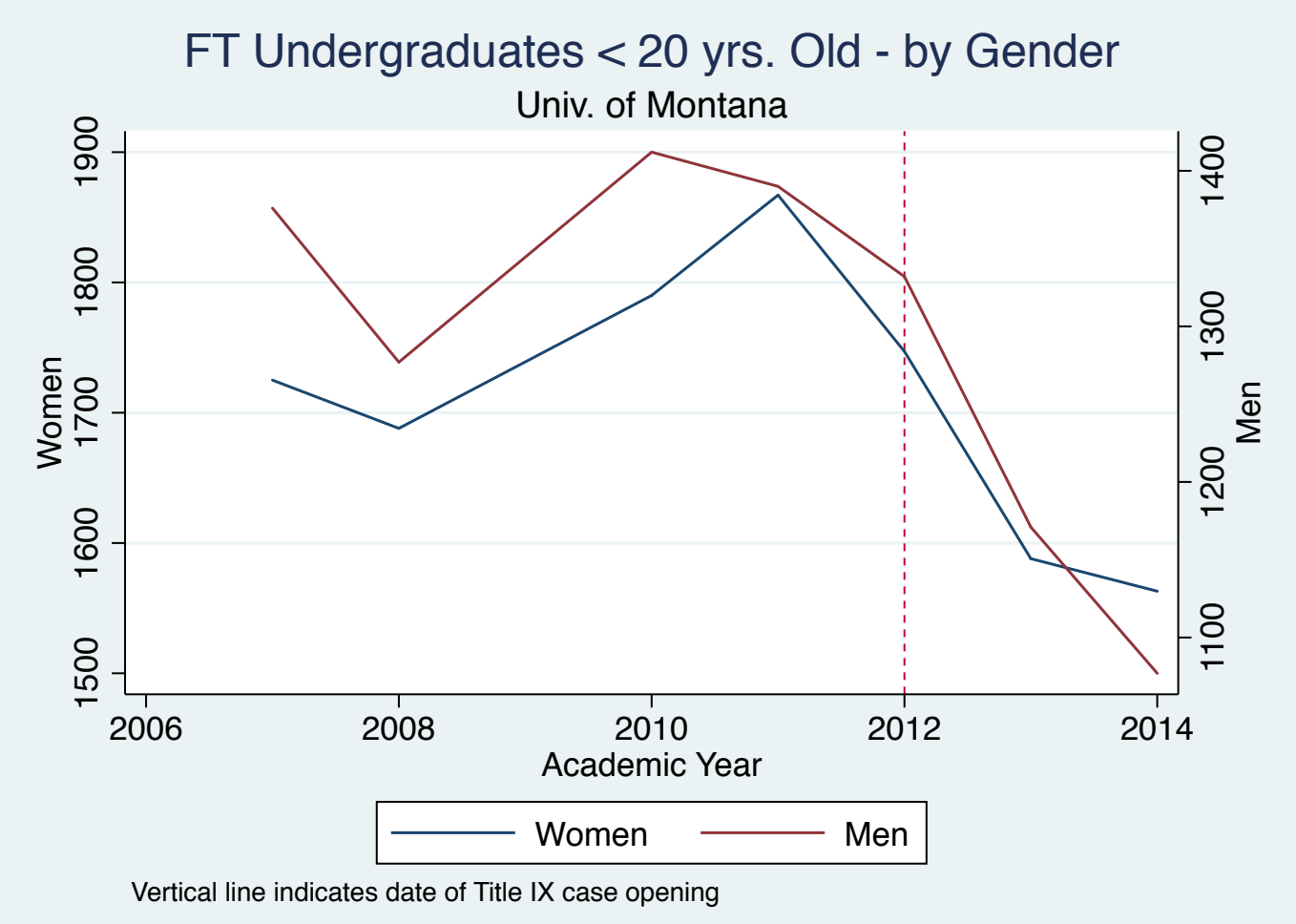

\section{Results}

Figure 3 provides a comparison of the 56 colleges and universities subject to Title IX investigations by late spring of 2014. Colleges subject to investigation were more likely to be large, research-intensive (R1) universities, either public or private. Approximately three-quarters of the institutions under Title IX investigation were in this category. Lower-tier, less selective schools (R2) were less represented among schools under investigation. 


\section{Figure 3}

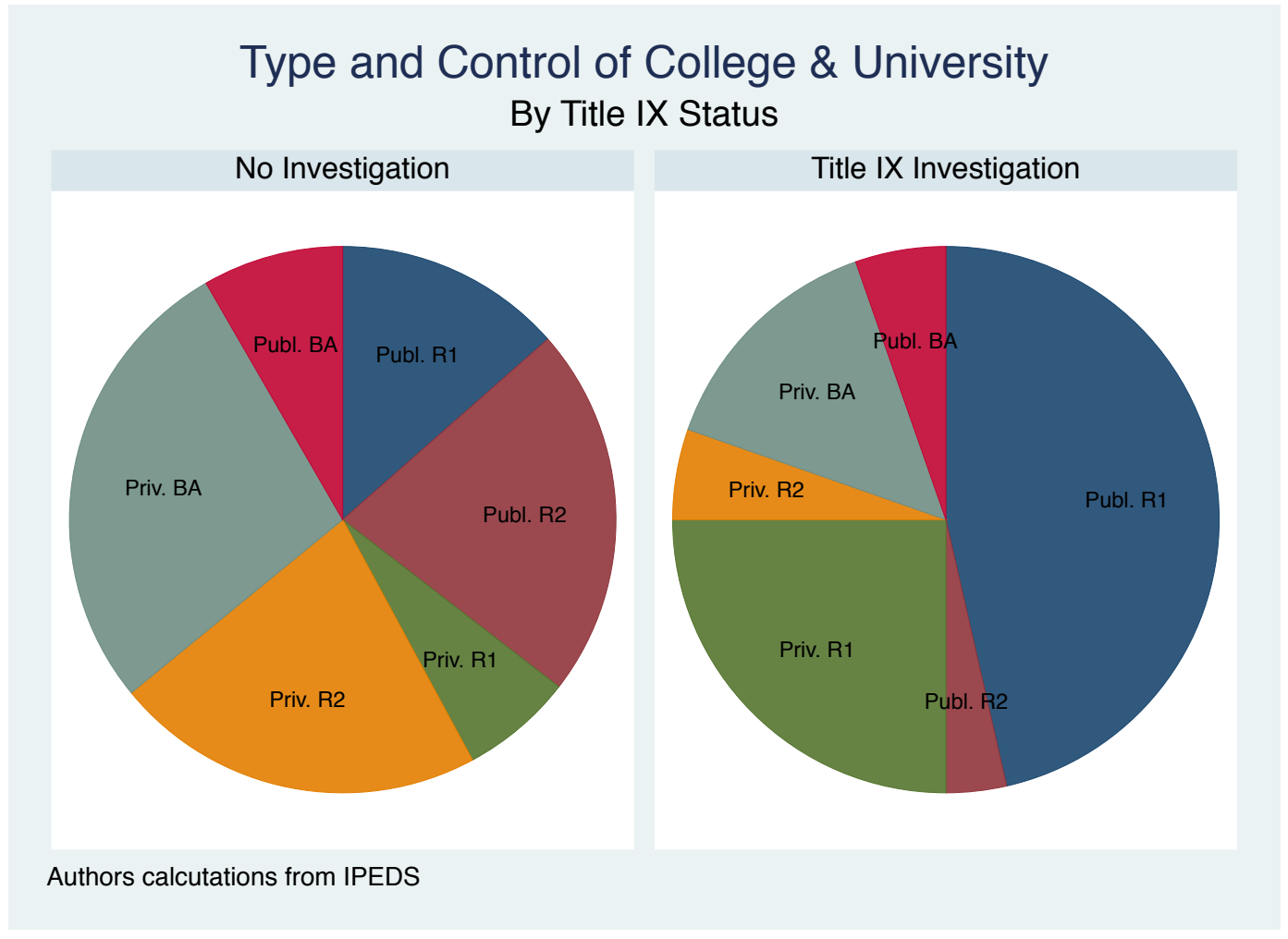

In Table 1 we provide additional comparative evidence of schools under investigation and those that were not. Schools under Title IX investigation are, on average, much larger, they are more selective and have higher graduation rates. Schools under investigation admit about half of applicants, compared to 63 percent for other schools, and SAT scores at the $75^{\text {th }}$ percentile are a full standard deviation higher. Remarkably, 1 in 4 schools under Title IX investigation are state flagship universities.

In Table 2 we present the results of our main empirical model. The first column presents the results of our model specified above. The next two columns differ only in how we model general enrollment changes over time. Model 2 includes a linear time trend, rather than controlling for year fixed-effects. Model 3 allows 
each age/gender group to have its own trend. Model 1 is less restrictive than 2, because growth in enrollment is not parametric. Model 3 is preferred if one believes that enrollment growth would be expected to differ between age/gender groups.

Since college fixed effects are included in all models, these estimates are robust to changes in unmeasured institutional attributes that might affect enrollment. The identifying assumption is that there are no unmeasured changes at a university that perfectly coincides with the opening of a Title IX investigation. Of course, it is possible that an investigation spurs response from a university's administration. This is not a confounder, however. Rather, it would be part and parcel of the investigation.

In column 1, we estimate that enrollment for women under 20 years of age declines approximately 16 percent when a university is under Title IX investigation, with even larger enrollment declines among undergraduates 20 and older (both estimates are significant at conventional levels). We find no similar declines in enrollment for men. Indeed, we estimate that enrollment among men increases, though not for older men. One explanation for this pattern is that enrollment changes for 17 to 19 year-old college students is driven mainly by changes in matriculation rates. Recall that schools under investigation are quite selective. So, a decline in the rate at which women apply, accept offers and enroll might actually benefit young men as spots at these institutions open up. For students beyond the Freshmen year, changes in enrollment are likely to be mainly driven by dropout. So, the relatively large enrollment decline for women is bad for the women involved, 
and bad for the institution, since these students can not be so readily replaced. The results from Models 2 and 3 are substantially and statistically similar.

In Table 3, we examine whether enrollment effects of Title IX investigations differ by college selectivity. To do so, we group institutions into three categories, based on their admissions rates. We define schools as "highly selective" if they admit less than half of applicants; "Selective" schools admit 50 to 75 percent of applicants, and; "Less selective" schools admit more than 75 percent. In all cases, the opening of a Title IX investigation decreases enrollment for women not in their teens - though the effect is increases with selectivity. Only for the highly selective schools is there also an effect on enrollment of women in their teens. And, only at these schools is there an increase in enrollment for men. This pattern is consistent with the possibility described above, that Title IX investigations and the atmosphere they signal dissuade young women from matriculating, but their places are taken at these highly selective schools by young men.

Next, we examine whether enrollment at an institution changes even before a Title IX investigation, and whether any enrollment losses are recouped in the subsequent year. To do this, we re-estimate our main model, but include lead/lag indicators for each student group. To summarize the 12 coefficients of interest, we plot the results in Figure 4. The figure illustrates the coefficients and 95\% confidence intervals for the indicator variables for each group one year before, the year of, and one year after a Title IX investigation was opened. Recall that these models control for institution, academic year, and student group fixed effects. So the coefficients measure changes in enrollment for a group over and above changes for 
that group in other years and changes for same group in other universities during the same year. We include a reference line at zero - the expected value if there was no unusual change in enrollment for a group/institution/year.

\section{Figure 4}

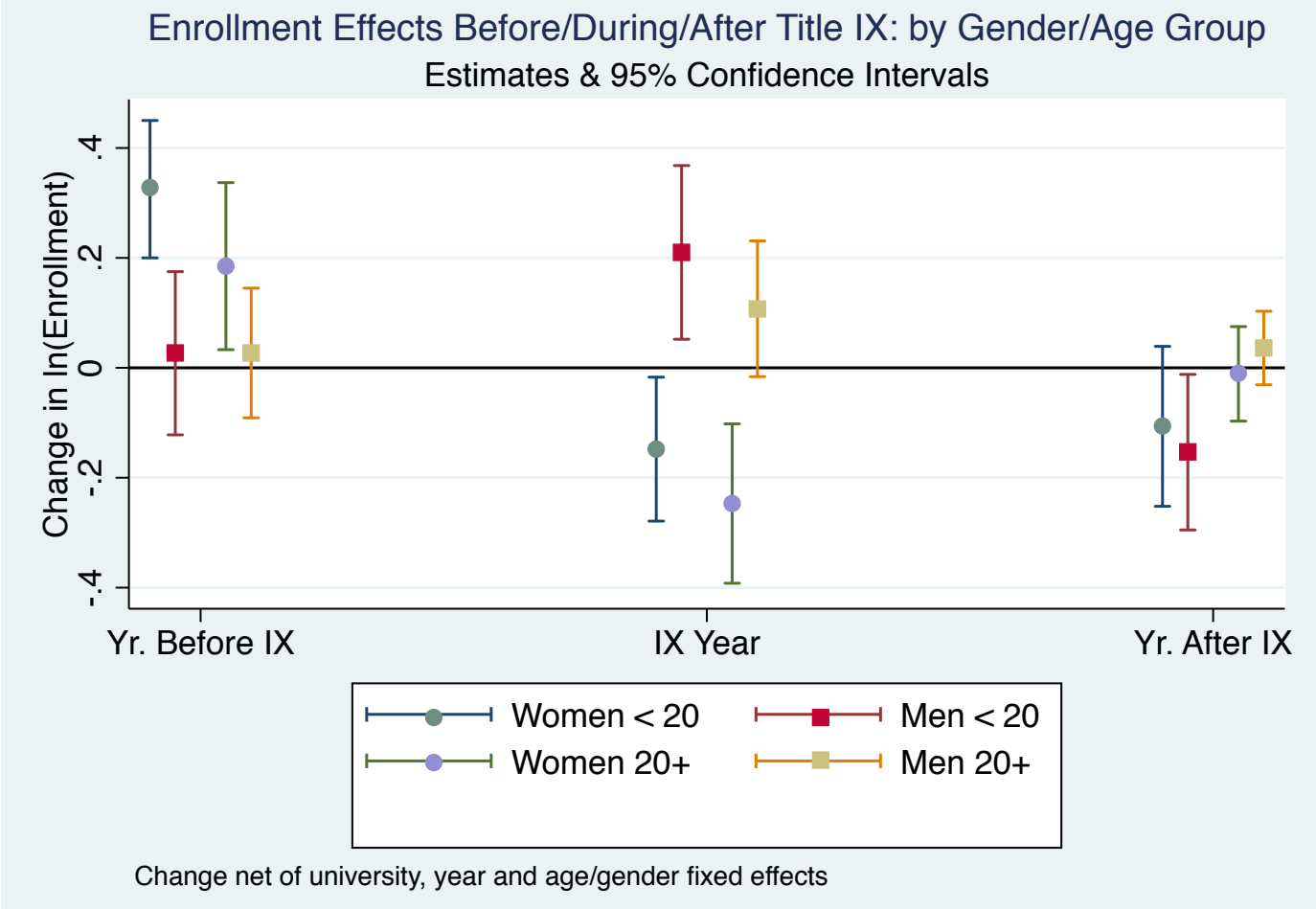

We find no evidence that enrollments decline in the year leading up to, or the year after a Title IX investigation is launched. One interpretation of the fact that there is no drop in enrollment in the leading academic year is that it provides a type of falsification check. Our main estimates of from Table 2 are not driven by declines in enrollment among women that simply happen to be coincident with a Title IX investigation. However, one might have expected a leading effect if the publicity of a high profile case preceded the OCR's action. However, our main coefficient may be 
picking up some of this since student enrollment likely changes slowly (as accepted students decline and current students transfer or fail to return).

\section{Discussion and Implications}

In this paper we assess the impact of high profile federal investigations of the handling of sexual assault claims at colleges and universities across the country. Notably, we examine the impact of these investigations on student enrollment, rather than on outcomes one might expect would be most directly affected, such as rates of sexual assaults, supports for victims, and punishments for perpetrators. One reason that we focus on this broader outcome is due to the difficulties inherent in measuring victimization (given the extent of underreporting by victims). But our focus on enrollment is also purposeful. Sexual victimization and how a university handles those claims affect students beyond those directly involved. Our focus is broad because the climate and perceptions of a campus can affect the student body generally, and especially female students.

Using a series of difference-in-differences estimates we find that enrollment of women drops sharply in response to the initiation of a Title IX inquiry. Further, using a triple-difference style comparison of women in contrast to men at institutions with/without Title IX investigations, we can rule out the possibility that subsequent enrollment declines were driven by other factors that made these institutions less attractive options for students. The enrollment patterns we find following the initiation of Title IX investigations are consistent with both declines in the rate of matriculation and retention of female students. 
We estimate that enrollment of teenage women at colleges under Title IX investigation declined by 16 percent, while the enrollment of undergraduate women from 20 to 22 years old declined more than 20 percent. If we use enrollment means for these schools, this implies a decline of 330 matriculation-aged women, and 730 retention-aged women at the average school under Title IX investigation. These numbers are driven in by the fact that Title IX schools are often state flagship universities, with large enrollments. By 2014, our estimates imply the college enrollment decisions of more than 30,000 women changed as a result of a Title IX investigation. To be sure, this is a small number relative to the more than 6.25 million women enrolled as full-time undergraduates at the time. Nonetheless, the enrollment changes induced by Title IX could certainly negatively affect the prospects of those involved, since more than two-thirds of the enrollment effect is due to declining retention.

Our results also suggest that the enrollment shifts due to Title IX investigations are short-lived, and essentially disappear after a year. This could be because news-cycles are often short. Or, it could be that the students most upset by an investigation leave immediately, and those remaining are less compelled to do so. A more optimistic interpretation to the short-term enrollment effects it that students at a campus under investigation perceive real changes being made in response.

It is important to recognize that the enrollment effects identified here pertain only to the early 2010s. In this period of the use of Title IX to investigate sexual assault was new, and the colleges and universities under investigation were 
relatively few. In the short time since the period studied here, the number of Title IX investigations has increased ten-fold. With so many cases open, and opening, college applicants and students today have fewer options to avoid a campus that has not been under investigation.

It remains to be seen if the recent attention to the issue affects rates of sexual violence on college campuses in the aggregate. Our paper illustrates that attention to the appearance of insufficient protections and processes at specific colleges had clear effects on the enrollment of women. That many women "voted with their feet" by leaving or avoiding institutions under investigation makes clear the stakes are high for colleges and universities. Since female students make up a sizeable majority of undergraduates, assuring that their safety and protection are paramount concerns will be essential for any college or university that hopes to thrive. The federal requirements of Clery and the 2013 recent reauthorization of VAWA mean that colleges and universities nationwide are increasing the amount, extent and quality of sexual assault prevention programming they offer on campus. Our findings indicate that the outcomes of these efforts are consequential. 


\section{References}

Aud, S., Hussar, W., Kena, G., Bianco, K., Frohlich, L., Kemp, J., Tahan, K. (2011). $e$ Condition of Education 2011 (NCES 2011-033). U.S. Department of Education, National Center for Education Statistics. Washington, DC: U.S. Government Printing Office.

Campbell, R., Dworkin, E., \& Cabral, G. (2009). An ecological model of the impact of sexual assault on women's mental health. Trauma, Violence, \& Abuse.

Cantalupo, N. C. (2011). Burying our heads in the sand: lack of knowledge, Knowledge avoidance and the persistent problem of campus peer sexual violence. Loyola University Chicago Law Journal, 43, 205.

Center for Public Integrity. 2010.

https://www.publicintegrity.org/2010/02/24/4360/lack-consequences-sexualassault

Fedina, L., Holmes, J. L., \& Backes, B. L. (2016). Campus Sexual Assault A Systematic Review of Prevalence Research From 2000 to 2015. Trauma, Violence, \& Abuse, 1524838016631129.

Dunn, L. L. (2013). Addressing Sexual Violence in Higher Education: Ensuring Compliance with the Clery Act, Title IX and VAWA. Geo. J. Gender \& L., 15, 563. Fisher, B. S., Cullen, F. T., \& Turner, M. G. (2000). The Sexual Victimization of College Women. Research Report.

Koss, M. P., Gidycz, C. A., \& Wisniewski, N. (1987). The scope of rape: incidence and prevalence of sexual aggression and victimization in a national sample of higher education students. Journal of consulting and clinical psychology, 55(2), 162.

Krakauer, J. (2015). Missoula: Rape and the justice system in a college town. New York, NY: Doubleday.

Krebs, C. P., Lindquist, C. H., Warner, T. D., Fisher, B. S., \& Martin, S. L. (2007). The campus sexual assault (CSA) study: Final report. Washington, DC: National Institute of Justice, US Department of Justice.

Kruttschnitt, C., Kalsbeek, W.D., \& House, C.C. (2014). Estimating the incidence of rape and sexual assault. Washington, DC: National Research Council.

Kilpatrick, D. G., Resnick, H. S., Ruggiero, K. J., Conoscenti, L. M., \& McCauley, J. (2007). Drug-facilitated, incapacitated, and forcible rape: A national study. National Criminal Justice Reference Service. 
National Public Radio. (2010). Seeking Justice for Campus Rapes. Washington DC: National Public Radio with the Center for Public Integrity. Retrieved from http://www.npr.org/series/124073905/seeking-justicefor-campus-rapes.

Richards, T. \& Kafonek, K. (2016). Reviewing state legislative agendas regarding sexual assault in higher education: Proliferation of best practices and points of caution. Feminist Criminology, 11(1), 91-129.

Schroeder, L. P. (2013). Cracks in the ivory tower: How the Campus Sexual Violence Elimination Act can protect students from sexual assault. Loy. U. Chi. LJ, 45, 1195.

U.S. Department of Education. (2016). The Handbook for Campus Safety and Security Reporting, 2016 Edition. Washington, D.C.: Office of Postsecondary Education.

Retrieved from http://www.ed.gov/admins/lead/safety/campus.html.

US Department of Justice, National Institute of Justice. (2008). Measuring Frequency. Retrieved from http://www.nij.gov/topics/crime/rape-sexualviolence/campus/pages/measuring.aspx 
Table 1 Descriptive Statistics of Colleges/Universities: By Title IX Status

\begin{tabular}{|c|c|c|}
\hline Variable & No Title IX Case & Title IX Case \\
\hline \multirow{2}{*}{ Enrollment (Headcount) } & 8022.8 & 17321.5 \\
\hline & 9351.2 & 15449 \\
\hline \multirow[t]{2}{*}{ Admission Rate } & 0.632 & 0.531 \\
\hline & 0.182 & 0.242 \\
\hline \multirow[t]{2}{*}{ Graduation Rate } & 0.533 & 0.727 \\
\hline & 0.186 & 0.17 \\
\hline \multirow[t]{2}{*}{ State Flagship? (0/1) } & 0.032 & 0.25 \\
\hline & 0.175 & 0.437 \\
\hline \multirow[t]{2}{*}{ Tuition/Fees } & $\$ 17,711$ & $\$ 21,486$ \\
\hline & 11920 & 14859 \\
\hline \multirow[t]{2}{*}{ Math SAT (75th ptile) } & 589.5 & 664.9 \\
\hline & 67.9 & 82.5 \\
\hline \multirow[t]{3}{*}{ Reading SAT (75th ptile) } & 581.9 & 653.1 \\
\hline & 67.1 & 78 \\
\hline & $\mathrm{n}=888$ & $n=56$ \\
\hline
\end{tabular}


Table 2 Enrollment Effects of Title IX Investigations

\begin{tabular}{|c|c|c|c|}
\hline Variable & Model 1 & Model 2 & Model 3 \\
\hline \multirow[t]{2}{*}{ Title IX x Women < 20} & $-0.159 * *$ & $-0.166 * *$ & -0.124 \\
\hline & 0.069 & 0.068 & 0.068 \\
\hline \multirow[t]{2}{*}{ Title IX x Men < 20} & $0.189^{*}$ & $0.181^{* *}$ & 0.144 \\
\hline & 0.082 & 0.082 & 0.082 \\
\hline \multirow[t]{2}{*}{ Title IX x Women >= 20} & $-0.242 * * *$ & $-0.250 * * *$ & $-0.221 * * *$ \\
\hline & 0.075 & 0.074 & 0.074 \\
\hline \multirow[t]{2}{*}{ Title IX x Men >= 20} & 0.114 & 0.106 & 0.081 \\
\hline & 0.062 & 0.062 & 0.063 \\
\hline \multirow[t]{2}{*}{ Admission Rate } & 0.045 & 0.038 & 0.033 \\
\hline & 0.027 & 0.027 & 0.027 \\
\hline \multirow[t]{2}{*}{ Pct. Receiving Aid } & 0 & 0 & 0.001 \\
\hline & -0.001 & -0.001 & -0.001 \\
\hline \multirow[t]{2}{*}{ Graduation Rate (6-year } & 0.127 & 0.129 & $0.149 * *$ \\
\hline & 0.077 & 0.076 & 0.076 \\
\hline \multirow[t]{2}{*}{ Bach Deg. As \% of All Degrees } & $0.175^{* * *}$ & $0.144^{* *}$ & $0.146^{* *}$ \\
\hline & 0.066 & -0.066 & -0.073 \\
\hline \multirow[t]{2}{*}{ Tuition \& Fees $(\$ 1,000 s)$} & -0.002 & -0.003 & -0.002 \\
\hline & 0.002 & 0.002 & 0.001 \\
\hline \multirow{2}{*}{ Time Trend } & & $0.017^{* * *}$ & $0.012 * * *$ \\
\hline & & 0.002 & 0.002 \\
\hline \multirow[t]{2}{*}{ Time Trend $\mathrm{x}$ Men $<20$} & & & 0 \\
\hline & & & 0.002 \\
\hline \multirow[t]{2}{*}{ Time Trend $\mathrm{x}$ Women $>=20$} & & & $0.005^{* *}$ \\
\hline & & & 0.002 \\
\hline \multirow[t]{2}{*}{ Time Trend $x$ Men $>=20$} & & & $0.008^{* * *}$ \\
\hline & & & 0.003 \\
\hline Institution FE? & Yes & Yes & Yes \\
\hline Student Group (Age/Gender) FE? & Yes & Yes & Yes \\
\hline Year FE? & Yes & No & No \\
\hline Time Trend? & No & Yes & Yes \\
\hline Student Group Time Trend? & No & No & Yes \\
\hline$H_{\circ}:$ Women $<20=$ Men $<20$ ( $p$-value $)$ & $<0.01$ & $<0.01$ & 0.012 \\
\hline $\mathrm{H}_{\circ}:$ Women $20+=$ Men $20+(p$-value $)$ & $<0.01$ & $<0.01$ & $<0.01$ \\
\hline R-squared & 0.817 & 0.817 & 0.898 \\
\hline $\mathrm{N}$ & 30171 & 30171 & 29771 \\
\hline
\end{tabular}

** $p<0.05, * * * p<0.01$

All models control for institution and student gro 25 (age/gender) fixed effects 
Table 3 Title IX Enrollment Effects: By College Selectivity

\begin{tabular}{|c|c|c|c|}
\hline Variable & -lighly Selective & Selective & Least Selective \\
\hline \multirow[t]{2}{*}{ Title IX x Women < 20} & $-0.207^{*}$ & -0.1 & -0.193 \\
\hline & 0.099 & 0.093 & 0.134 \\
\hline \multirow[t]{2}{*}{ Title IX x Men < 20} & $0.325^{* * *}$ & 0.188 & 0.001 \\
\hline & 0.094 & 0.128 & 0.108 \\
\hline \multirow[t]{2}{*}{ Title IX x Women >= 20} & $-0.314 * *$ & $-0.255^{*}$ & $-0.103^{*}$ \\
\hline & 0.097 & 0.126 & 0.052 \\
\hline \multirow[t]{2}{*}{ Title IX x Men >= 20} & 0.158 & 0.084 & $0.149 *$ \\
\hline & 0.082 & 0.093 & 0.065 \\
\hline \multirow[t]{2}{*}{ Admission Rate } & 0.089 & 0.066 & -0.076 \\
\hline & 0.133 & 0.059 & 0.09 \\
\hline \multirow[t]{2}{*}{ Pct. Receiving Aid } & 0.001 & 0 & 0 \\
\hline & 0.001 & 0.001 & 0.001 \\
\hline \multirow[t]{2}{*}{ Graduation Rate (6-year) } & 0.213 & 0.056 & 0.086 \\
\hline & 0.207 & 0.07 & 0.107 \\
\hline \multirow[t]{2}{*}{ Bach Deg. As \% of All Degrees } & -0.117 & $0.165^{*}$ & 0.107 \\
\hline & 0.177 & 0.071 & 0.09 \\
\hline \multirow[t]{2}{*}{ Tuition \& Fees (\$1,000s) } & 0.003 & -0.004 & -0.001 \\
\hline & 0.003 & 0.003 & 0.003 \\
\hline Institution FE? & Yes & Yes & Yes \\
\hline Student Group (Age/Gender) FE? & Yes & Yes & Yes \\
\hline Year FE? & Yes & Yes & Yes \\
\hline$H_{\circ}:$ Women $<20=$ Men $<20$ (p-value $)$ & $<0.01$ & 0.1978 & 0.2594 \\
\hline $\mathrm{H}_{\mathrm{o}}:$ Women $20+=$ Men $20+(p$-value $)$ & $<0.01$ & 0.4289 & 0.0584 \\
\hline R-squared & 0.79 & 0.83 & 0.802 \\
\hline $\mathrm{N}$ & 6169 & 14658 & 9344 \\
\hline
\end{tabular}

${ }^{*} \mathrm{p}<0.05,{ }^{* *} \mathrm{p}<0.01, * * * \mathrm{p}<0.001$ 